\title{
PB-PB ZIRCON AGES OF THE PORTO NACIONAL HIGH-GRADE METAMORPHIC TERRAIN, NORTHERN PORTION OF THE GOIÁS MASSIF, CENTRAL BRAZIL
}

\author{
PAULO SERGIO DE SOUSA GORAYEB ${ }^{1}$, CANDIDO AUGUSTO VELOSO MOURA ${ }^{1}$ \\ AND GISELE RIBEIRO DE BARROS ${ }^{2}$
}

\begin{abstract}
Single zircon Pb-evaporation ages were determined for a mafic granulite, two enderbites and a kinzigite of the Porto Nacional High-Grade Metamorphic Terrain (PNHGT) in the Goiás Massif. Zircons from mafic granulites and one of the enderbites yielded average ${ }^{207} \mathrm{~Pb} /{ }^{206} \mathrm{~Pb}$ ages of $2125 \pm 3 \mathrm{Ma}$ and $2153 \pm 1 \mathrm{Ma}$, respectively, being interpreted as minimum ages of the igneous protoliths. The other enderbite, whose zircons present round terminations, yielded an average ${ }^{207} \mathrm{~Pb} /{ }^{206} \mathrm{~Pb}$ age of $2097 \pm 2 \mathrm{Ma}$. Zircons from the kinzigite, displaying cores and rims overgrowth, presented ${ }^{207} \mathrm{~Pb} /{ }^{206} \mathrm{~Pb}$ ages ranging between 2072 and $2115 \mathrm{Ma}$. However, a very homogeneous zircon crystal without overgrowth yielded an age of $2100 \pm 2 \mathrm{Ma}$, with a distinctive low Th/U value (0.02). This zircon is interpreted as a metamorphic crystal and its age probably sets the age of the granulite facies metamorphism, indicating that the PNHGT is a result of the Tranzamazonian thermotectonic event.
\end{abstract}

Keywords: Geochronology, $\mathrm{Pb}-\mathrm{Pb}$ zircon, Granulite, Porto Nacional High-Grade Metamorphic Terrain

INTRODUCTION AND GEOLOGIC SETTING The Porto

Nacional region, central-south portion of the state of Tocantins, Brazil, is located in the Goiás Massif, which is an old crustal block surrounded by Neoproterozoic belts: the Araguaia Belt to the west and the Brasília Belt eastward. These major tectonic units are included in the Tocantins Province (Almeida et al. 1981). An extensive crustal segment, with pervasive NNE-SSW trending structures, occurs in the northern portion of the Goiás Massif. These structures are defined by a regional thrusting system that mixed rocks of different crustal levels, and extends southwardly to the Gurupi and Porangatu regions (Costa 1985, Costa et al. 1988a, Gorayeb 1996a) The geometry of the major litho-structural units defines anastomosed surfaces dipping at lowangle to SE with NW-SE stretch lineation. This crustal segment was named Tocantins Shear Belt (TSB) by Gorayeb (1996b) (Fig. 1). The gravimetric data in the Porto Nacional region are interpreted to represent crustal thickening where high-grade metamorphic rocks overthrusted gneissic terrains toward west, establishing an important N30E discontinuity (Hasui and Haralyi 1985, Costa et al. 1988b).

Along a traverse between the cities of Paraíso do Tocantins and Dianópolis, gneissic terrains (Rio dos Mangues, Manoel Alves complexes), metavolcano-sedimentary sequences (Rio do Coco Group, Morro do Aquiles Formation) granulitic terrains (Porto Nacional Complex) and granitoids are exposed for over $300 \mathrm{~km}$ (Hasui et al. 1984, Costa 1985, Gorayeb et al. 1988, Gorayeb 1996b, Moura and Souza 1996). All these units, which are cut by important NNE-SSW shear zones, were dismembered from the Goiano Complex (Cunha et al. 1981).

In spite of the reasonable geologic knowledge of this region, the geochronological information is very limited, and does not allow a reliable interpretation for the age of this crustal segment. An Archean evolution has been usually assigned to the gneissic terrains, the metavolcano-sedimentary sequences, the granulitic rocks and granitoids (Cunha et al. 1981, Danni et al. 1982, Hasui et al. 1984 Costa 1985, Gorayeb et al. 1988). However, more recent geochronological data have pointed to Upper Paleoproterozoic age for the gneisses of the Rio dos Mangues Complex (Moura and Souza 1996).

This study presents the results of the single zircon lead $(\mathrm{Pb})$ evaporation dating in granulitic rocks of the Porto Nacional High-Grade Metamorphic Terrain (PNHGT), which is one of the most important geologic unit of the TSB. The aim of this work is not only contribute for the geochronological knowledge of this region, but also to offer a preliminary discussion on the meaning of the new ages in the context of the TSB evolution.

\section{GEOLOGY OF THE PORTO NACIONAL HIGH-GRADE} METAMORPHIC TERRAIN The PNHGT is exposed in $100 \mathrm{~km}$ long NNE-SSW trending structure. Its maximum width is $35 \mathrm{~km}$, narrowing to the south until it disappears under the gneissic terrains. In

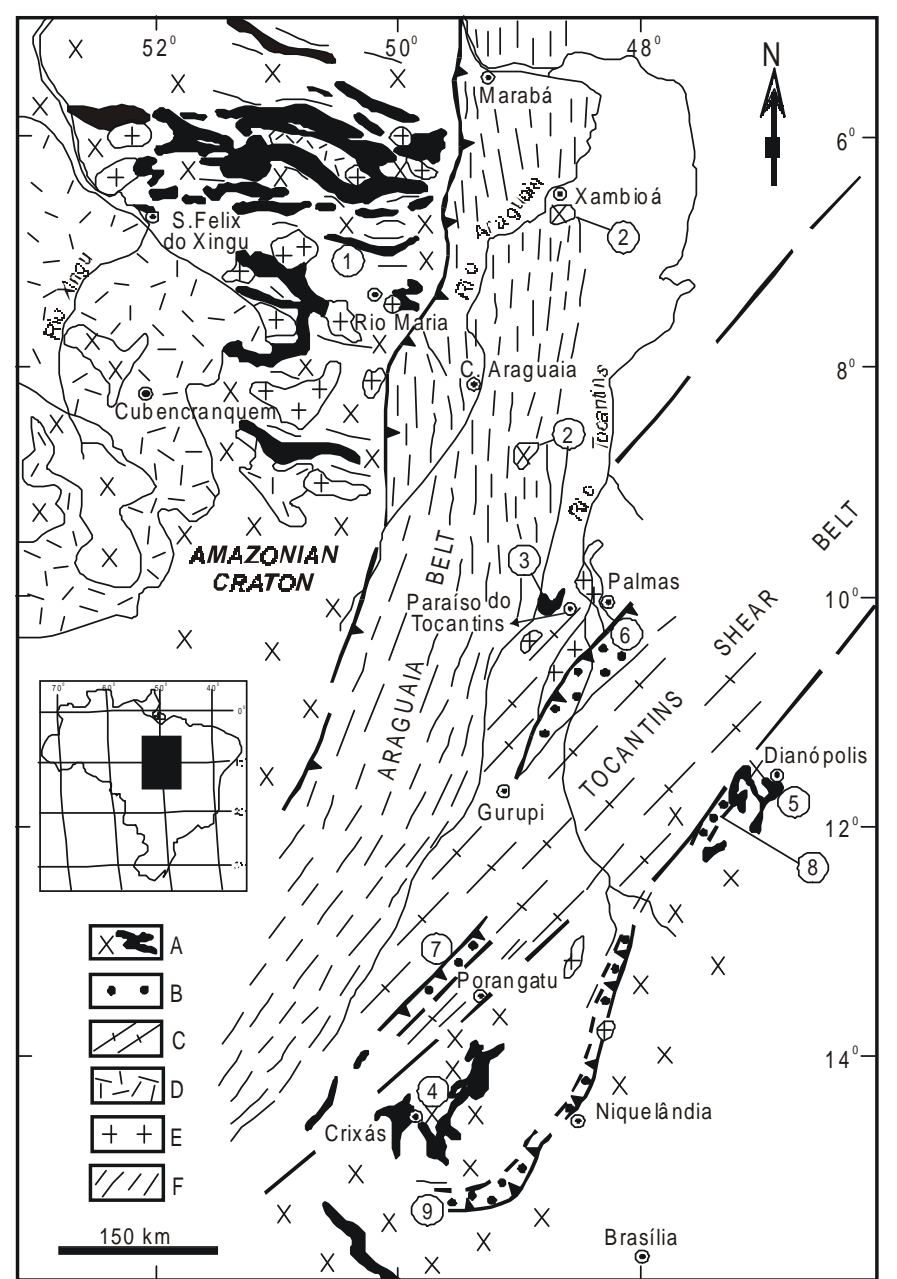

Figure 1-Major geological units of Central-Northern, Brazil, modified after Geologic Map of Brazil (1981). A-Archean Granite-Greenstone Terrain: 1) Rio Maria, 2) Colmeia, 3) Rio do Coco, 4) Crixás-Pilar de Goiás, (5) Dianópolis-Almas. B- Granulitic terrains: (6) Porto Nacional, (7) Porangatu, (8) Almas, (9) Goiás. C- Tocantins Shear Belt. D- Cratonic volcanosedimentary cover. E- Granitic Plutons. F-Araguaia Belt. 
the northeastern it is covered by the Paleozoic Parnaíba Basin (Fig. 2). In the southeast, normal faults put the PNHGT in contact with the lowgrade metassedimentary rocks of the Natividade Group, and generated grabens that were filled with conglomerates, arkoses and rhyolites of the Monte do Carmo Formation (2,0 Ga - Barradas et al. 1992, Gorayeb et al. 1992). The Matança Granite is a 555-560 Ma old batholith (Gorayeb et al. submitted) with tectonic emplacement between the PNHGT and the gneisses of the Rio dos Mangues Complex. The Palmas Granite, a $548 \pm 5$ Ma old pluton (Gorayeb et al. submitted), cuts the PNHGT in the north area (Fig. 2).

Two main, tectonically juxtaposed lithological-metamorphic units are present in the PNHGT. One of them (Porto Nacional Complex) was stabilized at medium to high pressure granulite facies and consists of mafic granulites, enderbites, kyanite and/or sillimanite-bearing garnet gneisses and anatectic granitic bodies (leucoenderbites, trondhjemites, S-type granites).

The other unit (Morro do Aquiles Formation) was subjected to high-amphibolite facies at low-middle pressure conditions. It main rock types are sillimanite and/or andalusite-bearing cordierite gneiss, tonalitic gneisses, graphite schists, gondites and amphibolites which are cross-cut by the Carreira Comprida Anorthosite (Fig. 2).

The PNHGT is composed of infra-crustal granulite facies rocks, which were imbricated and thrusted over gneissic terrains towards west representing a mega-slice of a tectonically exhumed lower crust.

PETROGRAPHY OF THE DATED ROCKS The rocks of the PNHGT selected for dating are mafic granulites and enderbites, which occur as concordant layers and irregular bodies associated with garnet gneisses (kinzigites). The mafic granulites are black, equigranular and fine to medium grained. Generally, they are massive or show a weak banding. They are composed of orthopyroxene, clinopyroxene, plagioclase and hornblende with minor garnet, opaque minerals, apatite, zircon and rare spinel. The granoblastic polygonal texture dominates and defines triple point junctions between orthopyroxene, clinopyroxene, plagioclase and hornblende. This texture reflects equilibrium conditions during the peak of granulite facies metamorphism that affected the PNHGT. Simplectite textures displayed by garnet-clinopyroxene-quartz-opaque association were formed by reactions involving orthopyroxene and plagioclase after the peak of the metamorphism. They are probably related to the higher pressures that resulted from crustal thickening during the collision tectonic responsible for the structural framework of the TSB.

The enderbites are dark or greenish gray, middle to coarse-grained granoblastic rocks. They are made up mainly of quartz and plagioclase with little or no K-feldspar, minor orthopyroxene, hornblende \pm clinopyroxene and biotite. A weak foliation is marked by biotite trails and banding is defined by quartz-feldspar layers.

The kinzigites are brown-colored, strongly banded quartz-feldspar gneisses. They are garnet-rich rocks with minor amounts of biotite, sillimanite/kyanite and graphite. Accessory minerals include zircon, rutile, apatite, ilmenite and magnetite. They present a dominant granoblastic texture with garnet porphyroblasts displaying intragranular trails of sillimanite, graphite, plagioclase and quartz. Feldspars are represented by antiperthitic plagioclase and perthitic microcline.

GEOCHRONOLOGY Analytical Procedures The ages of representative rocks of the PNHGT were obtained by the single zircon $\mathrm{Pb}$ evaporation technique $(\mathrm{Pb}-\mathrm{Pb}$ in zircon) established by Kober (1986, 1987). Four fresh rocks of the main lithotypes of the PNHGT were sampled for $\mathrm{Pb}-\mathrm{Pb}$ zircon age determination: one mafic granulite $(\mathrm{PN}-02 \mathrm{~A})$, two enderbites (PN-08.2, PN-23A), and one kinzigite (PN02B) (Fig. 2). The isotope analyses were carried out on a FINNIGANMAT 262 mass spectrometer at the Laboratório de Geologia Isotópica da Universidade Federal do Pará (Pará-Iso). The data acquisition was dynamically using the ion counting system of the instrument. $\mathrm{Pb}$ signal

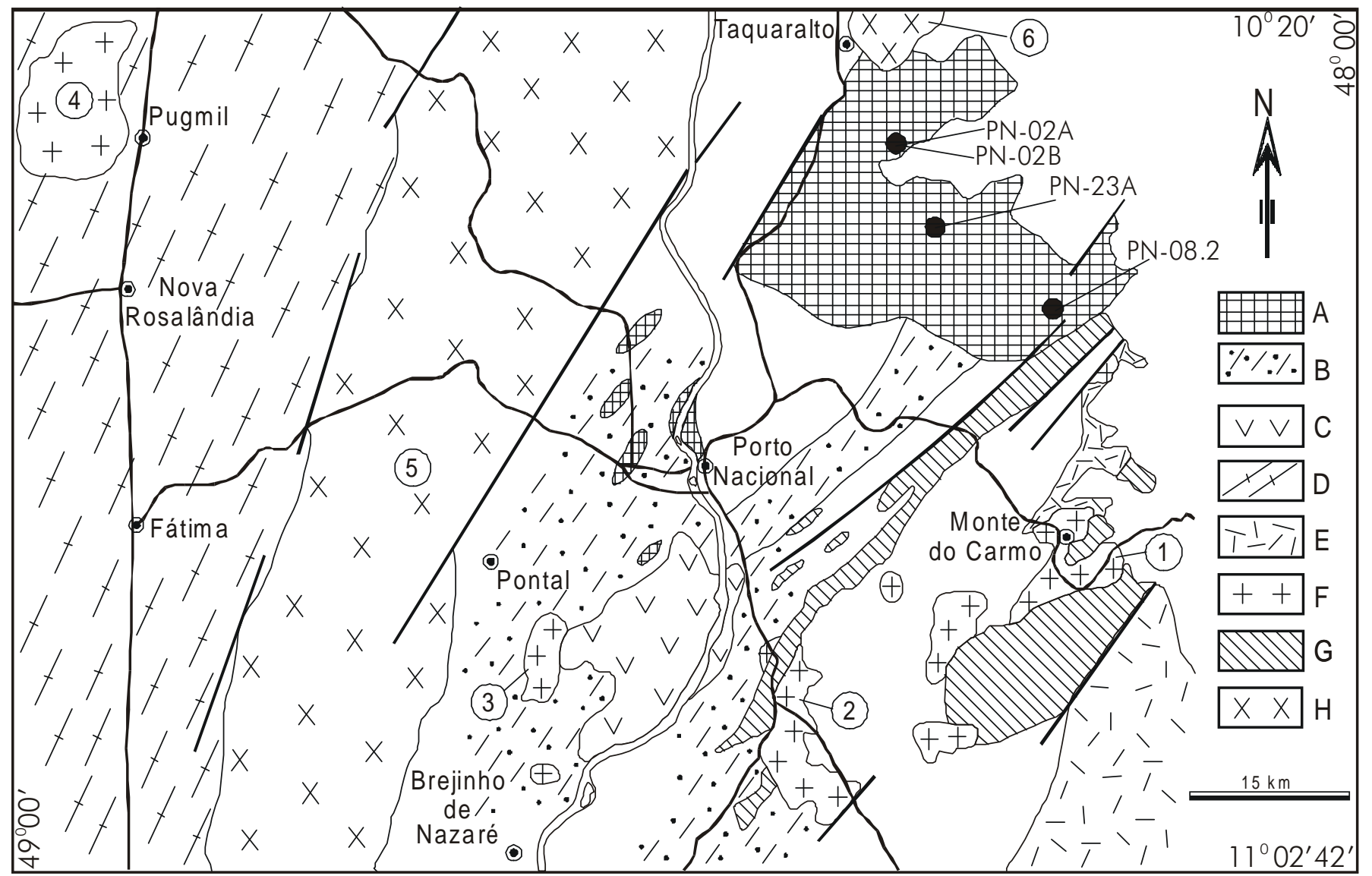

Figure 2-Geologic map of the Porto Nacional region modified after Gorayeb (1996). The sampling sites of the geochronological analyses are indicated. Paleoproterozoic units: A-Porto Nacional Complex; B- Morro do Aquiles Formation; C-Carreira Comprida Anorthosite; D- Rio dos Mangues Complex; EMonte do Carmo Formation; F- Granitic Plutons: (1) Carmo, (2) Areias, (3) Aroeira, (4) Serrote. Neoproterozoic units: G- Natividade Group; H- Granitic Plutons: (5) Matança, (6) Palmas. 
was collected by peak hopping in the order 206, 207, 208, 206, 207, 204 along 10 mass scans, defining one block of data with $18^{207} \mathrm{~Pb} /$ ${ }^{206} \mathrm{~Pb}$ ratios. Outliers were eliminated using Dixon's test. The average ${ }^{207} \mathrm{~Pb} /{ }^{206} \mathrm{~Pb}$ ratio of each step was determined based on five blocks, or till the intensity beam was sufficiently strong for a reliable analysis. The ${ }^{207} \mathrm{~Pb} /{ }^{206} \mathrm{~Pb}$ ratio was measured in three evaporation steps at temperatures of $1450^{\circ}, 1500^{\circ}$, and $1550^{\circ} \mathrm{C}$. Usually, the average ${ }^{207} \mathrm{~Pb} /$ ${ }^{206} \mathrm{~Pb}$ ratio obtained in the highest evaporation temperature was considered for age calculation. The ages were calculated with $2 \mathrm{~s}$ error and common $\mathrm{Pb}$ correction, for those blocks in which the ${ }^{204} \mathrm{~Pb} /{ }^{206} \mathrm{~Pb}$ ratios were lower than 0.0004 , was done using an appropriate age value derived from the model of Stacey and Kramers (1975). Th/U ratios for the zircons were estimated from time-integrated ${ }^{232} \mathrm{Th} /{ }^{238} \mathrm{U}$ values calculated from the present-day ${ }^{208} \mathrm{~Pb} /{ }^{206} \mathrm{~Pb}$ values for each heating steps, based on the respective age of the evaporation step (Bartlett et al. 1998). ${ }^{208} \mathrm{~Pb} / 206 \mathrm{~Pb}$ ratios were corrected for common $\mathrm{Pb}$ using also Stacey and Kramers (1975).

Results The zircon crystals of the mafic granulite (sample PN02A) are transparent, pale brown to yellowish, prismatic and dipyramidal. The ${ }^{207} \mathrm{~Pb} /{ }^{206} \mathrm{~Pb}$ ages for these crystals ranged from 2112 to $2134 \mathrm{Ma}$ along the three steps of evaporation (Table 1). Consistent ${ }^{207} \mathrm{~Pb} /{ }^{206} \mathrm{~Pb}$ ratios derived from successively higher temperatures of evaporation reflect the composition of radiogenic lead from regions slightly affected by lead loss (Kober 1986, 1987; Karabinos and Gromet 1993). Probably, each analyzed crystal is composed of a concordant homogeneous phase, without significant metamict component. The very low ${ }^{204} \mathrm{~Pb} /{ }^{206} \mathrm{~Pb}$ ratios of these crystals support this assumption. Four zircon crystals yielded an average ${ }^{207} \mathrm{~Pb} /{ }^{206} \mathrm{~Pb}$ age of $2125 \pm 3 \mathrm{Ma}$ (Table 1$)$. The Th/U values for the highest temperature of evaporation ranged roughly between 0.2 and 0.3 , which are in the field of magmatic zircons (Bartlett et al. 1998).

The zircon crystals of the enderbite PN-08.2 are transparent, pale brown to yellowish, and dominantly prismatic with pyramidal ends. $\mathrm{The}{ }^{207} \mathrm{~Pb} /{ }^{206} \mathrm{~Pb}$ ages of the crystals varied between 2130 and $2160 \mathrm{Ma}$ along the three steps of evaporation (Table 1), showing very consistent ${ }^{207} \mathrm{~Pb} /{ }^{206} \mathrm{~Pb}$ ratios similarly to the zircons of the mafic granulite. This consistency, along with the small ${ }^{204} \mathrm{~Pb} /{ }^{206} \mathrm{~Pb}$ ratios, also suggests the presence of homogeneous phases and the absence of significant metamict portions in these crystals. An average ${ }^{207} \mathrm{~Pb} /{ }^{206} \mathrm{~Pb}$ age of $2153 \pm 1$ Ma was obtained based on four zircon crystals. The Th/U ratios varying roughly between 0.2 and 0.3 are also in the range of the magmatic zircons (Table 1).

The zircon crystals of the enderbite PN-23A have similar size, length and color of those zircons of the sample PN-08.2. However, the prism and the pyramid ends of the crystals do not show well develop edges, but usually present round terminations, probably produced by metamorphic recrystallization. The ${ }^{207} \mathrm{~Pb} /{ }^{206} \mathrm{~Pb}$ ages of the crystals varied between 2088 and $2110 \mathrm{Ma}$ along the three steps of evaporation (Table 1). These very consistent values are accompanied by very low ${ }^{204} \mathrm{~Pb} /{ }^{206} \mathrm{~Pb}$ ratios. Four zircon crystals yielded an average ${ }^{207} \mathrm{~Pb} /{ }^{206} \mathrm{~Pb}$ age of $2097 \pm 2 \mathrm{Ma}$. This age is younger than that obtained for the enderbite PN-08.2 and may reflect a post-magmatic homogenization of the main phase of the zircon. This interpretation is suggested by the morphology (absence of edges and rounded terminations) of the zircon crystals of the enderbite PN-23A. In addition, most of the $\mathrm{Th} / \mathrm{U}$ ratios are lower than the values given by the enderbite PN-08.2 and the mafic granulite indicating the disturbance of the pristine zircon phase.

The kinzigite PN-02B was sampled in the same outcrop of the mafic granulite $\mathrm{PN}-02 \mathrm{~A}$. The zircon crystals are pale brown and stubby, with rounded termination. Observations under the polarized microscope show significant overgrowth in a number of crystals defining cores and rims. This morphology indicates that the zircons are not true metamorphic minerals but inherited crystals that underwent metamorphic overgrowth. The ${ }^{207} \mathrm{~Pb} /{ }^{206} \mathrm{~Pb}$ ages of the crystals varied between 2072 and $2115 \mathrm{Ma}$ along the three steps of evaporation (Table
1), approximately, the same range of the enderbite PN-23A. Since the zircons display cores and rims any ${ }^{207} \mathrm{~Pb} /{ }^{206} \mathrm{~Pb}$ average age is geologically meaningless. The $\mathrm{Th} / \mathrm{U}$ ratios range from very low value $(0.02)$ to values higher than 0.3 . The $\mathrm{Th} / \mathrm{U}$ ratios higher than 0.2 suggest a magmatic inheritance while those values lower than 0.2 may be interpreted as mixing of two end members: the inherited core and metamorphic overgrowth (rim). Since the zircon crystals show two distinct growth phases (core + rim), the older age obtained in crystal 9 $(2115 \pm 3 \mathrm{Ma})$ may be interpreted as minimum age of the core phase (Table 1). The crystal 1 is the only exception to this mixing feature. This zircon is very homogeneous, free of inclusions and without overgrowths. The very low $\mathrm{Th} / \mathrm{U}$ value is indicative that this zircon crystallized in a Th depleted environment, which is typical of the lower crust. Thus it is interpreted as a metamorphic zircon crystal.

DISCUSSIONS AND CONCLUSIONS The interpretation of ${ }^{207} \mathrm{~Pb} /{ }^{006} \mathrm{~Pb}$ evaporation age in single zircons of high-grade metamorphic rocks is not a simple task, since the $\mathrm{Pb}$-loss is variable within the single grains. Kröner et al. (1994) did not get concordant ${ }^{207} \mathrm{~Pb} /{ }^{206} \mathrm{~Pb}$ evaporation age in zircons from enderbites and charnockites of Sri-Lanka, and observed that the ${ }^{207} \mathrm{~Pb} /{ }^{206} \mathrm{~Pb}$ evaporation age may be lower than those in the original premetamorphic grains. Bartlett et al. (1998) interpreted progressively older ${ }^{207} \mathrm{~Pb} / 206 \mathrm{~Pb}$ evaporation zircon ages of polymetamorphic highgrade rocks as representing progressive amounts of mixing with an older core phase. They assumed the older age as the minimum age for the core phase. The average ${ }^{207} \mathrm{~Pb} /{ }^{206} \mathrm{~Pb}$ ages of $2125 \pm 3 \mathrm{Ma}$ and 2153 $\pm 1 \mathrm{Ma}$ obtained for the mafic granulite and enderbite PN-08.2, respectively, could be interpreted as magmatic crystallization ages, since the igneous characteristics of the zircons grains is well preserved, in spite of the granulite facies overprinted. Additionally, the ${ }^{207} \mathrm{~Pb} /$ ${ }^{206} \mathrm{~Pb}$ ratios of the zircons are very consistent along the successive steps of evaporation (Table 1). However, repeated evaporation analyses on zircons of the same sample yielding approximately the same ${ }^{207} \mathrm{~Pb} /$ ${ }^{206} \mathrm{~Pb}$ ratios is no guarantee that the same ratios measured approach those of the primary zircon formation, since such zircons may have lost their $\mathrm{Pb}$ in approximately equal proportions (Kröner et al. 1994). Thus, the average ${ }^{207} \mathrm{~Pb} /{ }^{206} \mathrm{~Pb}$ ages obtained for the mafic granulite and the enderbite PN-08.2 are interpreted as minimum ages for the zircon crystals of the igneous protolith.

The age of $2100 \pm 2 \mathrm{Ma}$ of the crystal 1 of the kinzigite may indicate the age of the granulite facies metamorphism (Table 1). The morphological features of this crystal and the contrasting very low $\mathrm{Th} /$ $\mathrm{U}$ ratio suggest a metamorphic crystallization for this zircon. This age overlaps within the errors the average ${ }^{207} \mathrm{~Pb} /{ }^{206} \mathrm{~Pb}$ zircon age of 2097 $\pm 2 \mathrm{Ma}$ for the enderbite PN-23A, whose zircon crystals present rounded terminations probably produced by the metamorphic process.

$\mathrm{Rb}-\mathrm{Sr}$ whole rock ages of $2010 \pm 98 \mathrm{Ma}$ and $2182 \pm 153 \mathrm{Ma}$ for the enderbites and mafic granulites, respectively, led Gorayeb and Lafon (1996) to confine the $2.0-2.2 \mathrm{Ga}$ interval to the thermo-tectonic event responsible for the granulite facies metamorphism of the PNHGT. The ${ }^{207} \mathrm{~Pb} /{ }^{206} \mathrm{~Pb}$ zircon ages obtained in this work permitted to define an age of $2.1 \mathrm{Ga}$ for this thermo-tectonic event. As a result, it is confirmed the Paleoproterozoic age of the PNHGT and its direct relationship with the Transamazonian thermo-tectonic event.

Due to limitation of the single zircon Pb-evaporation systematics in high-grade metamorphic rocks, the ages of the igneous protoliths of the PNHGT remain unknown. However, no indication of Archean age has been found in this work for these granulitic terrain. Additionally, the available ${ }^{207} \mathrm{~Pb} /{ }^{206} \mathrm{~Pb}$ zircon ages for the nearby geologic units suggest a major period of rock formation around 2.1 Ma in the northwest portion of the Goiás Massif (Gorayeb 1996b, Moura and Souza 1996). Based on the present geological and geochronological information it is suggested that this region was formed mainly during the Paleoproterozoic as a result of the Transamazonian orogenic collage. 
Table $1{ }^{207} \mathrm{~Pb}{ }^{206} \mathrm{~Pb}$ zircon ages of granulite facies rocks of the Porto Nacional High-Grade Metamorphic Terrain. Temp ${ }^{\circ} \mathrm{C}=$ temperatures of the evaporation steps; \# ratios $=$ number of 207/206 ratios used in the averaged age calculation over the total measured ratios; $207 / 206^{*}=$ ratios corrected for common Pb; $T h / U=$ estimated $T h / U$ ratio of the zircon for each evaporation step based on ${ }^{232} T h /{ }^{238} U$ and calculated from the basic radioactive decay equations $(N=D * /$ $\left.e^{l t}-1\right)$ and $N o=N+D^{*}$, using common $\mathrm{Pb}$ corrected present-day ${ }^{208} \mathrm{~Pb} /{ }^{206} \mathrm{~Pb}$ values for each heating step.

\begin{tabular}{|c|c|c|c|c|c|c|c|c|}
\hline \multicolumn{9}{|c|}{ PN-02A - MAFIC GRANULITE } \\
\hline ZIRCON & Temp. ${ }^{\circ} \mathbf{C}$ & \#ratios & $204 / 206$ & $208 / 206$ & $207 / 206$ & 207/206* & Age (Ma) & $\mathbf{T h} / \mathrm{U}$ \\
\hline \multirow[t]{3}{*}{ CRYSTAL 1} & 1450 & $0 / 90$ & $0.000064(38)$ & $0.08946(47)$ & $0.13269(28)$ & $0.13149(30)$ & $2118 \pm 4$ & 0.25 \\
\hline & 1500 & $86 / 86$ & $0.000149(53)$ & $0.09454(23)$ & $0.13432(31)$ & $0.13240(65)$ & $2130 \pm 9$ & 0.27 \\
\hline & 1550 & $84 / 84$ & $0.000096(31)$ & $0.09886(33)$ & $0.13425(40)$ & $0.13420(40)$ & $2134 \pm 7$ & 0.28 \\
\hline \multirow[t]{3}{*}{ CRYSTAL 2} & 1450 & $0 / 86$ & $0.000015(04)$ & $0.07649(19)$ & $0.13136(20)$ & $0.13116(23)$ & $2114 \pm 3$ & 0.22 \\
\hline & 1485 & $90 / 90$ & $0.000010(06)$ & $0.11160(185)$ & $0.13202(29)$ & $0.13185(38)$ & $2123 \pm 5$ & 0.31 \\
\hline & 1550 & $90 / 90$ & $0.000056(06)$ & $0.12101(45)$ & $0.13257(19)$ & $0.13172(25)$ & $2121 \pm 3$ & 0.34 \\
\hline CRYSTAL 3 & 1550 & $88 / 88$ & $0.000000(00)$ & $0.11709(41)$ & $0.13206(40)$ & $0.13206(40)$ & $2126 \pm 5$ & 0.33 \\
\hline \multirow[t]{3}{*}{ CRYSTAL 5} & 1450 & $0 / 14$ & $0.000082(20)$ & $0.04668(51)$ & $0.13207(65)$ & $0.13099(70)$ & $2112 \pm 9$ & 0.13 \\
\hline & 1500 & $86 / 86$ & $0.000030(03)$ & $0.05807(17)$ & $0.13244(18)$ & $0.13203(19)$ & $2125 \pm 2$ & 0.16 \\
\hline & 1550 & $82 / 82$ & $0.000099(10)$ & $0.09260(42)$ & $0.13390(52)$ & $0.13261(58)$ & $2133 \pm 8$ & 0.26 \\
\hline \multicolumn{4}{|l|}{ AVERAGE } & & & & $2125 \pm 3$ & \\
\hline \multicolumn{9}{|c|}{ PN-08.2 - ENDERBITE } \\
\hline \multirow[t]{3}{*}{ CRYSTAL 1} & 1450 & $0 / 88$ & $0.000029(28)$ & $0.10069(44)$ & $0.13336(18)$ & $0.13246(36)$ & $2131 \pm 5$ & 0.28 \\
\hline & 1500 & $0 / 88$ & $0.000004(03)$ & $0.10816(26)$ & $0.13313(19)$ & $0.13307(19)$ & $2139 \pm 2$ & 0.30 \\
\hline & 1550 & $0 / 82$ & $0.000017(04)$ & $0.11280(31)$ & $0.13299(24)$ & $0.13288(29)$ & $2137 \pm 4$ & 0.32 \\
\hline \multirow[t]{3}{*}{ CRYSTAL 2} & 1450 & $0 / 90$ & $0.000027(02)$ & $0.06740(52)$ & $0.13155(37)$ & $0.13121(41)$ & $2114 \pm 5$ & 0.19 \\
\hline & 1500 & $0 / 88$ & $0.000015(01)$ & $0.12202(89)$ & $0.13377(17)$ & $0.13358(17)$ & $2146 \pm 2$ & 0.34 \\
\hline & 1550 & $88 / 88$ & $0.000009(02)$ & $0.11723(44)$ & $0.13440(19)$ & $0.13428(20)$ & $2155 \pm 3$ & 0.33 \\
\hline \multirow[t]{3}{*}{ CRYSTAL 3} & 1450 & $0 / 84$ & $0.000012(03)$ & $0.09799(24)$ & $0.13351(20)$ & $0.13335(20)$ & $2143 \pm 3$ & 0.28 \\
\hline & 1500 & $86 / 86$ & $0.000002(02)$ & $0.10807(25)$ & $0.13417(18)$ & $0.13416(18)$ & $2153 \pm 2$ & 0.30 \\
\hline & 1550 & $66 / 66$ & $0.000004(04)$ & $0.10566(103)$ & $0.13461(60)$ & $0.13458(57)$ & $2159 \pm 7$ & 0.30 \\
\hline \multirow[t]{2}{*}{ CRYSTAL 4} & 1500 & $0 / 18$ & $0.000000(00)$ & $0.09570(416)$ & $0.13459(776)$ & $0.13459(776)$ & $2159 \pm 101$ & 0.27 \\
\hline & 1550 & $0 / 18$ & $0.000000(00)$ & $0.10589(57)$ & $0.13377(412)$ & $0.13377(412)$ & $2148 \pm 54$ & 0.30 \\
\hline CRYSTAL 5 & 1500 & $0 / 86$ & $0.000018(04)$ & $0.09250(27)$ & $0.13369(28)$ & $0.13343(30)$ & $2144 \pm 4$ & 0.26 \\
\hline \multirow[t]{3}{*}{ CRYSTAL 6} & 1450 & $84 / 84$ & $0.000074(02)$ & $0.09889(26)$ & $0.13509(29)$ & $0.13416(30)$ & $2153 \pm 4$ & 0.28 \\
\hline & 1500 & $84 / 84$ & $0.000015(04)$ & $0.09828(26)$ & $0.13414(18)$ & $0.13396(18)$ & $2151 \pm 2$ & 0.28 \\
\hline & 1550 & $34 / 34$ & $0.000037(229)$ & $0.10254(48)$ & $0.13435(54)$ & $0.13406(87)$ & $2152 \pm 11$ & 0.29 \\
\hline \multirow[t]{2}{*}{ CRYSTAL 7} & 1450 & $0 / 90$ & $0.000024(04)$ & $0.08680(50)$ & $0.13333(29)$ & $0.133304(24)$ & $2139 \pm 3$ & 0.24 \\
\hline & 1500 & $86 / 86$ & $0.000022(03)$ & $0.10319(27)$ & $0.13442(17)$ & $0.13417(18)$ & $2153 \pm 2$ & 0.29 \\
\hline \multicolumn{4}{|l|}{ AVERAGE } & & & & $2153 \pm 1$ & \\
\hline \multicolumn{9}{|c|}{ PN-23A - ENDERBITE } \\
\hline \multirow[t]{2}{*}{ CRYSTAL 1} & 1450 & $50 / 50$ & $0.000018(22)$ & $0.03960(35)$ & $0.13001(53)$ & $0.12978(48)$ & $2095 \pm 7$ & 0.11 \\
\hline & 1500 & $88 / 88$ & $0.000014(08)$ & $0.06301(41)$ & $0.13027(32)$ & $0.13018(31)$ & $2101 \pm 4$ & 0.18 \\
\hline CRYSTAL 6 & 1500 & $90 / 90$ & $0.000000(00)$ & $0.05959(36)$ & $0.12990(27)$ & $0.12990(27)$ & $2097 \pm 4$ & 0.17 \\
\hline \multirow[t]{2}{*}{ CRYSTAL 7} & 1500 & $70 / 70$ & $0.000000(00)$ & $0.03311(29)$ & $0.12993(30)$ & $0.12993(30)$ & $2097 \pm 4$ & 0.09 \\
\hline & 1550 & $0 / 36$ & $0.000000(00)$ & $0.04423(76)$ & $0.12923(49)$ & $0.12923(49)$ & $2088 \pm 7$ & 0.12 \\
\hline \multirow[t]{3}{*}{ CRYSTAL 8} & 1450 & $86 / 86$ & $0.000006(02)$ & $0.06821(70)$ & $0.12971(22)$ & $0.12967(20)$ & $2094 \pm 3$ & 0.21 \\
\hline & 1500 & $88 / 88$ & $0.000002(01)$ & $0.07624(23)$ & $0.13014(28)$ & $0.13012(27)$ & $2100 \pm 4$ & 0.23 \\
\hline & 1550 & $34 / 34$ & $0.000000(00)$ & $0.05589(48)$ & $0.13008(33)$ & $0.13008(33)$ & $2099 \pm 4$ & 0.17 \\
\hline CRYSTAL 11 & 1500 & $72 / 72$ & $0.000051(52)$ & $0.03617(52)$ & $0.13118(98)$ & $0.13090(102)$ & $2110 \pm 14$ & 0.11 \\
\hline AVERAGE & & & & & & & $2097 \pm 2$ & \\
\hline & & & & J-02B - KINZ & ZIGITE & & & \\
\hline CRYSTAL 1 & 1450 & $0 / 88$ & $0.000005(03)$ & $0.00826(8)$ & $0.13015(17)$ & $0.13012(17)$ & $2100 \pm 2$ & 0.02 \\
\hline CRYSTAL 2 & 1500 & $0 / 84$ & $0.000037(03)$ & $0.08396(151)$ & $0.12861(20)$ & $0.12811(20)$ & $2072 \pm 3$ & 0.24 \\
\hline CRYSTAL 3 & 1550 & $0 / 84$ & $0.000041(03)$ & $0.02782(16)$ & $0.12974(28)$ & $0.12923(28)$ & $2088 \pm 3$ & 0.08 \\
\hline CRYSTAL 4 & 1550 & $0 / 84$ & $0.000007(02)$ & $0.14370(42)$ & $0.13100(20)$ & $0.13089(20)$ & $2110 \pm 3$ & 0.40 \\
\hline CRYSTAL 5 & 1500 & $0 / 52$ & $0.000004(04)$ & $0.03374(115)$ & $0.13048(52)$ & $0.13046(55)$ & $2105 \pm 7$ & 0.10 \\
\hline CRYSTAL 7 & 1450 & $0 / 18$ & $0.000022(16)$ & $0.05708(31)$ & $0.12983(52)$ & $0.12954(52)$ & $2092 \pm 8$ & 0.16 \\
\hline & 1500 & $0 / 90$ & $0.000046(05)$ & $0.08682(23)$ & $0.12992(51)$ & $0.12930(51)$ & $2089 \pm 8$ & 0.24 \\
\hline CRYSTAL 9 & 1450 & $0 / 16$ & $0.000019(12)$ & $0.10647(64)$ & $0.12998(93)$ & $0.12973(95)$ & $2095 \pm 13$ & 0.30 \\
\hline & 1500 & $0 / 82$ & $0.000015(04)$ & $0.04392(18)$ & $0.13146(23)$ & $0.13128(23)$ & $2115 \pm 3$ & 0.12 \\
\hline CRYSTAL 10 & 1450 & $0 / 84$ & $0.000020(06)$ & $0.05926(23)$ & $0.13002(20)$ & $0.12981(24)$ & $2096 \pm 3$ & 0.17 \\
\hline & 1500 & $0 / 88$ & $0.000007(07)$ & $0.06323(29)$ & $0.12986(31)$ & $0.12981(29)$ & $2096 \pm 4$ & 0.18 \\
\hline & 1550 & $0 / 18$ & $0.000017(12)$ & $0.06650(56)$ & $0.13048(72)$ & $0.13025(72)$ & $2102 \pm 10$ & 0.19 \\
\hline
\end{tabular}




\section{References}

Almeida F.F.M., Hasui Y., Neves B.B.B., Fuck R.A. 1981. Brasilian structural provinces: an introduction. Earth Sci. Rev. 17:1-29.

Barradas J.A., Lafon J.N., Kotchoubey B. 1992. Geocronologia Pb-Pb e Rb-Sr da região de Monte do Carmo-Porto Nacional, Tocantins. Novos resultados. In: SBG, Congr Bras. Geol., 37, São Paulo. Anais, 2:182-183.

Bartlett J.M., Dougherty-Page J.S., Harris N.B.W., Hawkesworth C.J., Santosh M. 1998 The application of single zircon and model $\mathrm{Nd}$ ages to the interpretation of polymetamorphic terrains: an example from the Proterozoic mobile belt of south India. Contrib. Miner. Petrol. 131:181-195.

Costa J.B.S. 1985. Aspectos lito-estruturais e evolução crustal da região centro-norte de Goiás. Centro de Geociências, Universidade Federal do Pará, Belém, Ph.D. Thesis, $209 \mathrm{p}$.

Costa J.B.S., Hasui Y., Gorayeb P.S.S. 1988. Relações estruturais entre a Faixa Araguaia e o Maciço Goiano na região de Paraiso do Norte-Gurupi-GO. In: SBG, Congr. Bras. Geol., 35, Belém, Anais, 5:2187-2196.

Costa J.B.S., Hasui Y., Haralyi N.E. 1988. A zona de articulação dos blocos Brasilia e Araguacema no centro-norte de Goiás. In: SBG, Congr. Bras. Geol., 35, Belém, Anais 5:2197-2207.

Cunha B.C, Potiguar L.A.T., Ianhez A.C., Bezerra P.E.L., Pitthan J.M.L., Souza J.J. Montalvão R.M.G., Souza A.M.S., Hildred T.R., Tassinari C.C.C. 1981. Projeto Radambrasil, Levantamento de recursos naturais, Folha SC.22-Tocantins, Geologia Rio de Janeiro. 21-196

Danni J.C.M., Fuck R.A., Leonardos D.H. 1982. Archean and lower proterozoic units in Central Brazil. Geol. Rundsch., 71:291-317.

Gorayeb P.S.S. 1996b. Petrologia e evolução crustal das rochas de alto grau de Porto Nacional-TO. Centro de Geociências, Universidade Federal do Pará, Belém, Ph. D. Thesis, 261p.

Gorayeb P.S.S. 1996b. A Faixa Granulítica de Porangatu-TO: Caracterização lito-estrutural e tectono-metamórfica. In: SBG, Congr. Bras. Geol., 39, Salvador, Anais, 6:303 305.

Gorayeb P.S.S., Costa J.B.S., Lemos R.L., Gama T., Bemerguy R.L., Hasui Y. 1988. O PréCambriano da região de Natividade-GO. Rev. Bras. Geoc. 18:391-397.
Gorayeb P.S.S. \& Lafon J.M. 1996. Resultados geocronológicos Rb-Sr como indicadores do metamorfismo granulítico de Porto Nacional-TO. In: SBG, Congr. Bras. Geol., 39, Salvador. Anais, 6:300-301.

Gorayeb P.S.S., Moura C.A.V., Arcanjo, S.H. (Submitted). Granitogenesis events in the Porto Nacional-Palmas-Paraiso do Tocantins region. In: $31^{\text {st }}$. Intern. Geol. Congr., Rio de Janeiro, Brazil-2000.

Hasui Y. \& Haralyi N.L.E. 1985. A megaestruturação de Goiás. In: SBG, Simp. Geol. Centro-Oeste, 2, Goiânia, Atas, 1:1-18.

Hasui Y., Costa J.B.S., Gorayeb P.S.S., Lemos R.L., Gama T., Bemerguy R.L. 1984. Geologia da região de Paraiso do Norte de Goiás, GO. In: SBG, Cong. Bras. Geol., 33, Rio de Janeiro, Anais, 5:2220-2233.

Karabinos P. \& Gromet L.P. 1993. Applications of single-grain zircon evaporation analyses to detrital grain studies and age discrimination in igneous suites. Geoch. Cosmoch. to detrital grain studies

Kober B. 1986. Whole grain evaporation for ${ }^{207} \mathrm{~Pb} /{ }^{206} \mathrm{~Pb}$ age investigations on single zircons using a double filament source. Contrib. Mineral. Petrol. 93:482-490.

Kober B. 1987. Single grain evaporation combined with $\mathrm{Pb}+$ emitter bedding for ${ }^{207} \mathrm{~Pb} /{ }^{206} \mathrm{~Pb}$ investigations using thermal ion mass spectrometry, and implications for zirconology. Contrib.Mineral. Petrol. 96:63-71.

Krönner .A., Jaeckel P., Williams I.S. 1994. Pb-loss patterns in zircons from a high-grade metamorphic terrain as revealed by different dating methods: $\mathrm{U}-\mathrm{Pb}$ and $\mathrm{Pb}-\mathrm{Pb}$ ages for igneous and metamorphic zircons from northern Sri Lanka. Precamb. Res. 66:151-181

Moura C.A.V. \& Souza S.H.P. 1996. Síntese dos dados geocronológicos das rochas do embasamento do Cinturão Araguaia e suas implicacões estratigráficas. In: SBG, Congr. Bras. Geol., 39, Salvador, Anais, 6:31-34.

Stacey J.S. \& Kramer J.D. 1975. Approximation of terrestrial lead isotope evolution by a two-stage model. Earth Planet. Sci. Lett. 26:207-221.

Contribution IGC-189 Received March 10, 2000 Accepted for publication May 15, 2000 